\title{
Social Responsibility Programs may Strengthen the Medical Students' Role to Fight against COVID-19 Pandemic
}

Dilek Aslan', [MD]

ORCID: 0000-0002-4053-2517

Meral Demirören², [MD]

ORCID: 0000-0001-7415-9602

Bürge Atılgan², [MD]

ORCID: 0000-0002-2800-4957

Selim Güler ${ }^{3}$, [MD]

ORCID: 0000-0002-6949-0920

Ülkücan Kaplan", [PhD]

ORCID: 0000-0002-3239-5516

Pergin Atilla ${ }^{5}$, [MD]

ORCID: 0000-0001-5132-0002

Fazıl Tuncay Aki ${ }^{5}$, [MD]

ORCID: 0000-0002-3625-9968

Bülent Altun ${ }^{6}$, [MD]

ORCID: 0000-0002-2687-8861

'Hacettepe University, Faculty of Medicine, Department of Public Health, Sıhhiye, Ankara

${ }^{2}$ Hacettepe University, Faculty of Medicine, Department of Medical Education and Informatics, Sıhhiye, Ankara

${ }^{3}$ Sinop Provincial Health Directorate

${ }^{4}$ Hacettepe University, Faculty of Medicine, Department of History of Medicine and Medical Ethics

${ }^{5}$ Vice Dean, Hacettepe University, Faculty of Medicine

${ }^{6}$ Dean, Hacettepe University, Faculty of Medicine

Corresponding Author: Dilek Aslan

Hacettepe University Faculty of Medicine, Department of Public Health 06100, Sıhhiye, Ankara Turkey.

E-mail: diaslan@hacettepe.edu.tr

\section{w ABSTRACT Con}

Objective: We aimed to explain the details of the "We, as well, are in the Fight Against Novel Coronavirus Disease (COVID-19)!" "online" Social Responsibility Project as a model to be used in medical education in the COVID-19 fight. The Project has been developed as a part of Phase 1 Medicine and Social Responsibility Program at Hacettepe University, Faculty of Medicine in Turkey, and aimed to increase the social responsibility, awareness and sensitivity of the students in COVID-19 pandemic days.

Material and Methods: All project phases were developed in collaborative work with Faculty Dean's Office, Project Coordination Team, facilitators, and project groups student representatives. The Project was conducted online in May 2020 in 33 student groups, each of which comprised 10-15 students and an academic staff of the Faculty. All materials were shared simultaneously via the official website of Hacettepe University Faculty of Medicine.

Results: Various types of materials like reminders, infographics, videos, and other visuals have been prepared for the Project. Students shared all these materials via social media such as Instagram, Facebook, WhatsApp groups. International students translated some materials into different languages to share the materials in their home-countries. The materials were prepared by Project Coordination Team by having the opinions and suggestions of the faculty members and students.

Conclusion: Social Responsibility Project is thought to facilitate improving the sensitivity of the students in COVID-19 crisis. The Project has also contributed to improve the students' capacity in the management of infodemic and accessing to the community.

Keywords: Social responsibility, medical education, medical students, COVID-19 fight. 


\section{INTRODUCTION}

Novel Coronavirus Disease (COVID-19) pandemic has reminded the gaps in medical education to respond to extraordinary situations in healthrelated issues. All sectors question their positions to fill such gaps to be prepared for possible future situations.

As pandemic has more than one-dimension, medical students should be prepared for not excluding community component. It is quite understandable that unexpected and abrupt situations due to the pandemic interrupted to respond to the needs properly. However, systematic, and community-based programs to cover the needs of the population can be helpful for this purpose.

In Turkey, face-to-face education was interrupted in medical faculty due to the measures taken to be prevented from COVID-19 pandemic and medical students had to stay at home as a restrictive measure of the Government. Because of their age, Phase 1 students had to stay at home due to legal legislations.

"We, as well, are in the Fight Against Novel Coronavirus Disease (COVID-19)!" "online" Social Responsibility Project has been developed as a part of Phase 1 Medicine and Social Responsibility Program to increase the social responsibility, awareness and sensitivity of the students in pandemic days. The Project has objectives for the students like learning evidence-based scientific information on the issue and experiencing to feel the responsibility in sharing the correct information with the population. Such experience is expected to be an important achievement for medical students who are the physicians of the future.

In this paper, we aimed to explain the details of the project as a model to be used in medical education in the COVID-19 fight.

\section{MATERIAL and METHODS}

All project development and implementation phases were developed in collaborative work with Faculty Dean's Office, Project Coordination Team, facilitators, and project groups student representatives.

Due to the limited social life, students informed the target groups via web-based communication methods. Information and other steps of the Project were planned, implemented, and monitored in 33 project groups under the guidance of the facilitators. The originally produced materials were shared by the students with the target groups via social media such as Instagram, Facebook, WhatsApp groups between May 15 and 31, 2020. All materials were shared simultaneously via the official website of Hacettepe University Faculty of Medicine.

Four major target groups, including general society, 65 years and older individuals and individuals with chronic diseases, teenagers (children staying at home-adolescent), and women who have just given birth were determined as the project groups.

Ethical approval was not obtained for this paper as the content is focused on the explanation of the Program content.

\section{RESULTS}

Various types of materials like reminders, infographics, videos, and other visuals have been prepared for the Project. Students shared the content using all these materials. International students of the Faculty translated some materials into different languages to share the materials in their home-countries. The materials were prepared by the BPSR Coordination team by having the opinions and suggestions of the faculty members and students. The details of the materials are shown in Table 1. Figure 1 shows selected prepared materials produced in Turkish. 
Table 1. Materials of the "We, as well, are in the fight against COVID-19!" Project

\begin{tabular}{|c|c|c|}
\hline Material type (number) & Content & Language \\
\hline Reminder (14) & $\begin{array}{l}\text { 1. General Information on COVID-19 } \\
\text { 2. Proper Hand Washing } \\
\text { 3. Social / Physical Distancing! } \\
\text { 4. Wearing Face Masks Properly } \\
\text { 5. Risk Groups } \\
\text { 6. COVID-19 and Adolescent-1 } \\
\text { 7. COVID-19 and Adelosanes-2 } \\
\text { 8. COVID-19 and Adolescent-3 } \\
\text { 9. COVID-19 and Tobacco Use } \\
\text { 10. COVID-19 and } 65 \text { Years of Age and Older People } \\
\text { 11. } 10 \text { Recommendations for Children, Adolescents and Parents } \\
\text { 12. COVID-19 and Breastfeeding } \\
\text { 13. COVID-19 and Foods } \\
\text { 14. COVID-19 and Correct Information Sources }\end{array}$ & Turkish \\
\hline Infographics (5) & $\begin{array}{l}\text { 1. Social / Physical Distancing! } \\
\text { 2. Wearing Face Masks Properly } \\
\text { 3. COVID-19 and Tobacco Use } \\
\text { 4. COVID-19 and } 65 \text { Years of Age and Older People } \\
\text { 5. } 10 \text { Recommendations for Children, Adolescents and Parents }\end{array}$ & $\begin{array}{l}\text { Turkish } \\
\text { English } \\
\text { Arabic } \\
\text { Albanian } \\
\text { Greek } \\
\text { Azeri } \\
\text { Swahili }\end{array}$ \\
\hline Video (1) & 1. Messages from HUFM Phase I Students & Arabic with English subtitle \\
\hline Video (2) & 2. Narrative; "Pathetic End" of "Novel Coronavirus" & Turkish \\
\hline
\end{tabular}

The Project ended at the end of May 2020. Written and/or oral feedback of the students and consultants have been taken during June and July 2020. Reflections of the students were also taken.

\section{DISCUSSION}

Novel Coronavirus Disease COVID-19 highlighted the need for paradigm shift on medical education. Various thoughts have been shared in this context ${ }^{1}$. Public health perspective in medical education should be strengthened as COVID-19 has demonstrated the need to improve in participation, collaboration, and advocacy responsibilities of the physicians into the public health systems as graduates of medical faculties ${ }^{2}$. Medical education systems should prepare their graduates with this perspective in which different models fitting to the local needs looking at the "bigger" picture at the global level.

\section{CONCLUSION}

In conclusion, "We, as well, are in the Fight Against Novel Coronavirus Disease (COVID-19)!" is thought to facilitate to improve the sensitivity of the students in the COVID-19 crisis. The Project has also contributed improving the students' capacity in the management of infodemic and accessing the community. Similar Projects should be developed and implemented in the routine medical education system to be much more prepared for the future crisis as a routine body of the education system in the global perspective.

\section{LIMITATIONS}

Online feature of the Project is the major limitation of the Project. 


\section{ACKNOWLEDGEMENTS}

We are thankful to the students and mentors of the Program for their great support and efforts during the Project.

\section{CONFLICT Of INTEREST}

The authors declare that there is no conflict of interests.

\section{weO REFERENCES CQm}

[1] Ferrel MN, Ryan JJ. The Impact of COVID-19 on Medical Education. Cureus. 2020; 12(3):e7492. Published 2020 Mar 31. doi:10.7759/cureus.7492.

[2] Maeshiro R, Carney JK. Public Health Is Essential: COVID-19's Learnable Moment for Medical Education [published online ahead of print, 2020 May 20]. Acad Med. 2020;10.1097/ACM.0000000000003517. doi:10.1097/ ACM.0000000000003517.
[3] Yeni Koronavirüs Hastalığı http://www.tip.hacettepe. edu.tr/koronavirus/yenikoronavirus.php (Accessed date: 13.03.2021).

[4] İnfografikler http://tip.hacettepe.edu.tr/ekler/php/ infografikler.php (Accessed date:13.03.2021). 